\title{
Analisis Kepuasan Pelanggan Terhadap Sarana Prasarana dan Lokasi Perumahan Menggunakan Metode Quality Function Deployment (Studi Kasus Perumahan Griya Pesona Karangrejo Banyuwangi)
}

\author{
(Analysis Of Costumers Satisfication To Residence Facilities, Infrastructure And Location Uses \\ Quality Function Deployment Method (A Case Study Griya Pesona \\ Karangrejo Recidence Banyuwangi))
}

Mangesti Carissa Putri, Dewi Junita Koesoemawati, Anita Trisiana

Jurusan Teknik Sipil, Fakultas Teknik, Universitas Jember (UNEJ)

Jln. Kalimantan 37, Jember 68121

E-mail: anita.teknikunej@gmail.com

\begin{abstract}
Abstrak
Perumahan merupakan kebutuhan yang sangat penting bagi masyarakat. Kepuasan konsumen atas pembelian rumah yang ditawarkan merupakan impian dari setiap pengembang. Perumahan Griya Pesona Karangrejo Banyuwangi merupakan kawasan perumahan yang sedang berkembang ke tahap 4. Penelitian ini bertujuan untuk mengetahui kondisi eksisting suatu perumahan apakah sudah sesuai dengan standar perumahan yang ada, mengetahui variabel yang menjadi prioritas dari konsumen berdasarkan kualitas produk, sarana prasarana, lokasi dan kualitas pelayanan menggunakan metode QFD (Quality Function Deployment) dan penentuan strategi perbaikan yang harus dilakukan oleh pengembang menggunakan analisis IPA (Importance Performance Analysis). Pengumpulan data dilakukan dengan cara wawancara dan penyebaran kuisioner kepada penghuni perumahan.Dari hasil penelitian didapatkan hasil identifikasi kondisi eksisting dilapangan, Perumahan Griya Pesona Karangrejo Banyuwangi belum sepenuhnya memenuhi standar perumahan yang ada. Urutan variabel yang diprioritaskan diambil 5 variabel yang terbesar dari raw weight yaitu sarana ruang terbuka hijau, perkerasan jalan/paving, keamanan terhadap banjir, lebar dan kondisi jalan utama dan fasilitas pembuangan air kotor/drainase. Dalam penentuan strategi perbaikan berdasarkan analisis IPA pengembang harus melakukan perbaikan jalan sesuai dengan standar dan membangun saluran drainase sesuai standar serta melakukan pengecekan terhadap kualitas produk sebelum diserahkan kepada konsumen.
\end{abstract}

Kata Kunci: Kepuasan konsumen, QFD (Quality Function Deloyment), IPA (Importance Performance Analysis).

\section{Abstract}

A residence is a very important necessity for society. The satisfaction of consumers for the purchase of the house offered is the dreams of every developer. Griya Pesona Karangrejo Banyuwangi residence is a residence area that was developing to stage 4. The aims of the research are to know the existing condition that has been appropriated with the residence standart there, for knowing what are the variables to become consumer priority based on quality of product, infrastructure, location and service quality using QFD (Quality Function Deployment) method, and the determination of strategy development that must do using IPA (Importance Performance Analysis) analysis. The data collection has done by interview and spreading questionnaire of the resident. The result of the research obtained the identification of existing condition in the field, Griya Pesona Karangrejo Banyuwangi residence has not completely fulfilled the standart residence there. The sequence variable that is prioritized had taken 5 variables of the biggest of RawWeight which means green open space, road/paving, safety against flooding, width and main road conditions and waste water disposal facilities/drainage. In determining the improvement strategy based on the development of IPA analysis should make the road repairs according to the standards, build the appropriate drainage channels standards and conduct checks on the quality of the product before submitted to the consumers.

Keywords: The consumer satisfaction, QFD (Quality Function Deloyment), IPA (Importance Performance Analysis) analysis.

\section{PENDAHULUAN}

Perumahan merupakan kebutuhan yang sangat penting bagi masyarakat. Produk-produk yang ditawarkan oleh pengembang kepada konsumennya tentunya harus berorientasi kepada kebutuhan konsumen. Kepuasan konsumen atas pembelian rumah yang ditawarkan merupakan impian dari setiap pengembang. Masyarakat yang semakin maju membutuhkan keamanan, kenyamanan dalam lingkungan perumahaan atau huniannya. Beberapa perumahan baru di kawasan perkotaan Kabupaten
Banyuwangi tidak dapat memberikan manfaat optimal bagi penghuninya. Beberapa kompleks perumahan tersebut hanya dihuni sedikit penduduk, dan hanya berupa sekumpulan rumah dalam pengertian fisik tanpa ditunjang sarana dan prasarana yang memadai. [2]

Perumahan Griya Pesona Karangrejo adalah salah satu perumahan yang ada di Banyuwangi, dikembangkan oleh PT. Sobo Asri. Perumahan Griya Pesona Karangrejo, dibagi menjadi 4 tahap dan akan merencanakan tahap ke 5. Pada tahap 1 terdapat 117 unit rumah yang sudah dihuni, pada tahap 2 terdapat 127 unit rumah yang sudah dihuni dan 
tahap 3 terdapat 128 unit rumah yang sudah dihuni, sedangkan pada tahap 4 masih pada proses pembangunan dan hanya dihuni sekitar 20 rumah Pada perumahan ini hanya terdapat satu tipe rumah, yaitu tipe 36 . Ditinjau kondisi di lapangan, kualitas produk, sarana dan prasarana yang ada di perumahan tersebut masih belum memadai seperti akses jalan utama masuk perumahan yang kurang bagus serta banyaknya sampah yang berserakan dikawasan jalan utama masuk perumahan. Ada juga beberapa warga sekitar yang mengeluh akan kondisi serta kualitas rumah yang mereka tinggali (Hasil Observasi).

Untuk mengetahui lebih lanjut mengenai kepuasan penghuni perumahan terutama pada kualitas, sarana, prasarana dan lokasi yang disediakan atau yang ada pada Perumahan Griya Pesona Karangrejo Banyuwangi dengan menggunakan metode Quality Function Deployment (QFD) yang digunakan untuk menerjemahkan apa saja yang dibutuhkan konsumen dan yang diharapkan konsumen pada Perumahan Griya Pesona Karangrejo Banyuwangi serta penentuan strategi perbaikan menggunakan Importance Performance Analysis (IPA).

\section{METODE PENELITIAN}

\section{Lokasi Penelitian}

Penelitian ini dilaksanakan di Perumahan Griya Pesona Karangrejo Banyuwangi. Perumahan ini beralamat di jalan Ikan Paus, Karangrejo Banyuwangi. Perumahan ini dibangun oleh PT. Sobo Asri.

\section{Langkah Penelitian}

Penelitian dilakukan secara urut dan sistematis sesuai dasar teori permasalahan, sehingga didapatkan analisis yang akurat untuk mencapai tujuan penulis. Tahapan dalam penelitian ini sebagai berikut:

1. Studi literature

Didapat dari referensi literatur yang ada terutama yang berkaitan dengan dengan penelitian ini, kemudian menentukan rumusan masalah.

\section{Pengumpulan data}

Data yang dibutuhkan dalam penelitian adalah data primer dan data sekunder. Data primer melalui wawancara dan kuisioner kepada pihak developer PT Sobo Asri dan penghuni Perumahan Griya Pesona Karangrejo. Data sekunder meliputi Keputusan Menteri Permukiman dan Prasarana Wilayah No. 403/KPTS/M/2002 tentang Pedoman Teknis Pembangunan Rumah Sederhana Sehat (Rs SEHAT), SNI 03-6967-2003 tentang Persyaratan Umum Sistem Jaringan dan Geometrik Jalan Perumahan, dan SNI 03-1733-2004 tentang Tata Cara Perencanaan Lingkungan Perumahan di Perkotaan, gambar (site plan, denah, tampak), dan spesifikasi bangunan.

3. Perancangan variabel

Variabel dalam penelitian ini yaitu kualitas produk, kualitas pelayanan, sarana dan prasarana serta lokasi.

4. Penentuan jumlah sampel

Pengambilan sampel berdasarkan atas random sampling, karena pengambilan sampel dari populasi dilakukan secara acak tanpa memperhatikan strata yang ada dalam populasi itu. Salah satu metode yang digunakan untuk menentukan jumlah sampel adalah menggunakan rumus Slovin [6] sebagai berikut:

$$
\mathrm{n}=\frac{N}{N d^{2}+1}
$$

\section{Perancangan kuisioner}

Kuisioner pada penelitian ini melalui dua tahap yaitu kuisioner pendahuluan dan kuisioner utama.

6. Penyebaran kuisioner

Penyebaran kuisioner dilakukan dua tahap yaitu penyebaran kuisioner pendahuluan dan penyebaran kuisioner utama.

7. Uji validitas

Berfungsi untuk menguji valid atau tidaknya suatu variabel penelitian.

8. Uji reliablitias

Berfungsi untuk menguji konsistensi suatu variabel penelitian.

9. Menyusun house of quality

Menghitung nilai tingkat kepentingan pelanggan (importance to customers), nilai tingkat kepuasan pelanggan (customers satisfaction performance), nilai target (goal), nilai tingkat kesenjangan (gap), nilai improvement ratio, nilai raw weight dan nilai normalized raw weight.

10. Analisis IPA

Analisis IPA dilakukan dengan cara nilai kepuasan pelanggan dihubungkan dengan nilai kepentingan pelanggan pada setiap variabel sehingga dapat diketahui variabel tersebut berada dalam kuadran prioritas berapa.

\section{Menentukan strategi perbaikan}

Strategi perbaikan di dapat dari analisis IPA.

12. Pembahasan dan kesimpulan

Pembahasan menjelaskan tentang perhitungan yang telah dianalisis. Kesimpulan disebut juga pengambilan keputusan. Pada tahap ini, data yang telah diolah dibuat suatu kesimpulan yang hubungannya berkaitan dengan tujuan dari penelitian.

\section{HASIL DAN PEMBAHASAN}

\section{Identifikasi Kondisi Eksisting Perumahan Dengan Standar Perumahan}

Identifikasi dilakukan dengan cara pengamatan langsung atau observasi langsung di Perumahan Griya Pesona Karangrejo. Perumahan ini mempunyai luas lahan sebesar $54.741 \mathrm{~m}^{2}$. Pada perumahan ini hanya terdapat satu tipe rumah yaitu tipe 36 . Dilakukan 16 identifikasi variabel yaitu denah rumah, jumlah kamar, sirkulasi udara dan efektifitasnya, kualitas pencahayaan, jaringan air bersih, jaringan air limbah, jaringan drainase, jaringan listrik, jaringan jalan, sarana ruang terbuka hijau, penerangan jalan, jaringan persampahan, taman dan lapangan olahraga, sarana perniagaan, sarana kesehatan dan sarana peribadatan. Berdasarkan hasil identifikasi dengan standar yang digunakan yaitu Keputusan Menteri Permukiman dan Prasarana Wilayah No. 403/KPTS/M/2002 tentang Pedoman Teknis Pembangunan Rumah Sederhana Sehat (Rs SEHAT), SNI 03-6967-2003 tentang Persyaratan Umum Sistem Jaringan dan Geometrik Jalan Perumahan, Undang-Undang No. 26 Tahun 2007 tentang penataan ruang dan SNI 03-1733-2004 tentang Tata Cara Perencanaan Lingkungan Perumahan di Perkotaan, 8 
variabel diantaranya memenuhi standar dan 8 diantaranya belum memenuhi standar. Sehingga Perumahan Griya Pesona Karangrejo belum dapat memenuhi keinginan penghuni.

\section{Sampel penelitian}

Sebagai populasi adalah penghuni Perumahan Griya Pesona Karangrejo Banyuwangi tahap 1, 2 dan 3. Populasi yang terdapat dalam penelitian tahap 1 sebanyak 117 unit, tahap 2 sebanyak 127 unit dan tahap 3 sebanyak 128 unit. dan nilai presisi tingkat kesalahan 0,1 (10\%), dengan menggunakan rumus pada persamaan (1) maka besarnya sampel penelitian sebagai berikut:

1. Tahap 1

$$
n=\frac{117}{1+117(0,1)^{2}}=53,917 \approx 54 \text { Sampel }
$$

2. Tahap 2

$$
n=\frac{127}{1+127(0,1)^{2}}=55,947 \approx 56 \text { Sampel }
$$

3. Tahap 3

$$
n=\frac{128}{1+128(0,1)^{2}}=56,140 \approx 57 \text { Sampel }
$$

Sehingga didapatkan dari tahap 1 sebanyak 54 sampel, tahap 2 sebanyak 56 sampel dan tahap 3 sebanyak 57 sampel. Dapat disimpulkan keseluruhan sampel sebanyak 167 sampel.

\section{Penyebaran Kuisioner Pendahuluan}

Penyebaran kuisioner pendahuluan dilakukan kepada 15 responden pada tahap 1, 2 dan 3 penghuni Perumahan Griya Pesona Karangrejo Banyuwangi dengan jumlah 50 variabel yang terdapat dalam kuisioner pendahuluan.

\section{Uji Validitas}

Pada uji validitas menggunakan rumus korelasi Bivariate Person dengan alat bantu SPSS 24.0. Variabel kuisioner pada pengujian ini, dikatakn valid jika nilai rhitung $>$ r-tabel pada nilai signifikan 5\%. Sebaliknya, variabel dikatakn tidak valid apabila nilai r-hitung $<$ r-tabel pada nilai signifikan 5\%. Hasil uji validitas terdapat 25 variabel yang valid dan 1 variabel tambahan dari responden.

\section{Uji Reliabilitas}

Uji reliabilitas menggunakan rumus Alpha Pearson dengan bantuan software SPSS 24.0. Variabel pada kuisioner pendahuluan dalam uji reliabilitas dikatakan reliabel apabila nilai Alpha $>0,60$. Sebaliknya, apabila nilai Alpha $<0,60$ dikatakan tidak reliabel. Hasil uji reliabilitas terdapat 25 variabel yang reliabel dan 1 variabel tambahan dari responden.

\section{Penyebaran Kuisioner Utama}

Penyebaran kuisoner utama dilakukan kepada 167 responden penghuni Perumahan Griya Pesona karangrejp pada tahap 1, 2 dan 3. Jumlah variabel yang digunakan untuk kuisioner utama sebanyak 26 variabel yang didapatkan dari kuisioner pendahuluan yang telah diuji validitas dan reliabilitas. Variabel yang digunakan untuk menilai kepuasan pelanggan dapat dilihat pada Tabel 1:

\begin{tabular}{|c|c|c|c|}
\hline No & Variabel & No. & Variabel \\
\hline \multicolumn{2}{|c|}{ A. Kualitas Produk } & 14 & Fasilitas listrik \\
\hline \multicolumn{2}{|c|}{1 Denah rumah } & 15 & $\begin{array}{l}\text { Lebar dan kondisi } \\
\text { jalan utama }\end{array}$ \\
\hline \multicolumn{2}{|c|}{2 Jumlah kamar } & 16 & $\begin{array}{l}\text { Lebar dan kondisi } \\
\text { jalan di depan } \\
\text { rumah }\end{array}$ \\
\hline & $\begin{array}{l}\text { Kualitas bahan yang } \\
\text { digunakan dalam } \\
\text { pembangunan }\end{array}$ & 17 & $\begin{array}{l}\text { Sarana ruang } \\
\text { terbuka hijau / } \\
\text { pemakaman }\end{array}$ \\
\hline 4 & Ketahanan atap rumah & 18 & Penerangan jalan \\
\hline 5 & $\begin{array}{l}\text { Ketahanan dinding } \\
\text { terhadap keretakan } \\
\text { struktur }\end{array}$ & 19 & $\begin{array}{l}\text { Perkerasan jalan / } \\
\text { paving }\end{array}$ \\
\hline \multicolumn{2}{|r|}{$\begin{array}{l}6 \text { Kerusakan cat dinding } \\
\text { dalam rumah }\end{array}$} & \multicolumn{2}{|c|}{ C. Lokasi } \\
\hline & $\begin{array}{l}\text { Ketahanan lantai } \\
\text { terhadap keretakan }\end{array}$ & 20 & $\begin{array}{l}\text { Keamanan lokasi } \\
\text { perumahan }\end{array}$ \\
\hline 8 & Ketahanan plafon & 21 & $\begin{array}{l}\text { Keamanan } \\
\text { terhadap banjir }\end{array}$ \\
\hline 9 & $\begin{array}{l}\text { Sirkulasi udara dan } \\
\text { efektivitasnya }\end{array}$ & 22 & $\begin{array}{l}\text { Intensitas } \\
\text { pengangkutan } \\
\text { sampah }\end{array}$ \\
\hline 10 & Kualitas pencahayaan & 23 & $\begin{array}{l}\text { Keamanan } \\
\text { perumahan } \\
\text { terhadap keributan }\end{array}$ \\
\hline \multicolumn{2}{|c|}{ B. Sarana Prasarana } & \multicolumn{2}{|c|}{ D. Kualitas Pelayanan } \\
\hline & $\begin{array}{l}\text { Fasilitas penyediaan air } \\
\text { bersih / PDAM }\end{array}$ & 24 & $\begin{array}{l}\text { Kepedulian akan } \\
\text { kritik dan saran }\end{array}$ \\
\hline 12 & $\begin{array}{l}\text { Fasilitas pembuangan } \\
\text { air limbah / air kotor }\end{array}$ & 25 & $\begin{array}{l}\text { Perhatian akan } \\
\text { kebutuhan } \\
\text { penghuni }\end{array}$ \\
\hline 13 & $\begin{array}{l}\text { Fasilitas pembuangan } \\
\text { air hujan / drainase }\end{array}$ & 26 & $\begin{array}{l}\text { Tanggung jawab } \\
\text { menepati janji }\end{array}$ \\
\hline
\end{tabular}

Tabel 1. Variabel Kepuasan Pelanggan yang Valid dan Reliabel

(Sumber: Hasil Pengolahan Data)

\section{Penyusunan House of Quality}

House of Quality menjelaskan apa yang menjadi kebutuhan pelanggan dan bagaimana pemenuhan konsumen. House of Quality dibuat berdasrkan penggabungan pengolahan data dari penetuan kepentingan sampai dengan respon teknis.[1]

Penyusunan House of Quality dapat dilihat pada Gambar 1

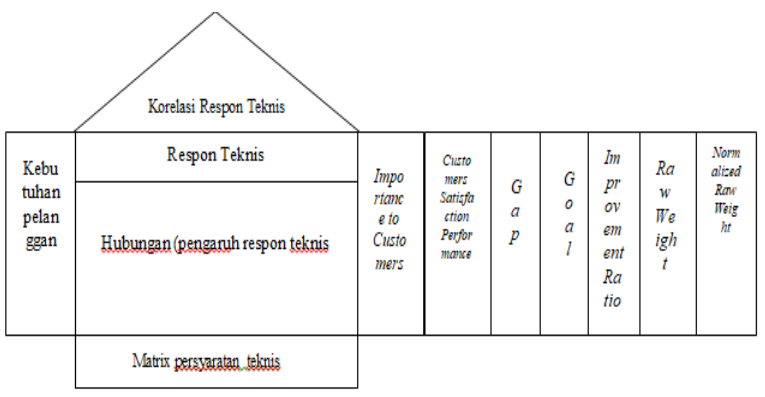

Gambar 1. House of Quality 
1. Tingkat kepentingan pelanggan (Importance to Customers)

$$
\text { Importance to Customers }=\begin{gathered}
j u m l \text { ah res ponden } \\
\sum \text { Performance weight } \frac{\dot{i}}{\dot{i}}
\end{gathered}
$$

2. Tingkat kepuasan pelanggan (Customers Satisfaction Performance)

$$
\text { Customers Satisfaction Performance }=\begin{gathered}
\text { jumlah res ponden } \\
\sum \text { Performance weight }(s p) \frac{\dot{i}}{\dot{i}}
\end{gathered}
$$

3. Goal

Goal dilakukan wawancara dengan pihak developer PT Sobo Asri

4. Gap

$$
\text { Gap = Customers Satisfaction Performance - Importance to Customers }
$$

5. Improvement Ratio

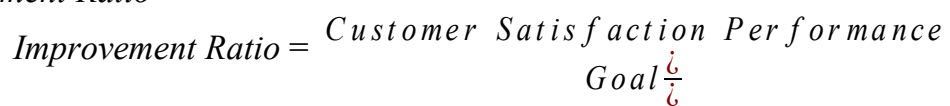

6. Raw Weight

$$
\text { Raw weight }=\text { Importance to Customers } x \text { Improvement Ratio }
$$

7. Normalized Raw Weight

\begin{tabular}{|c|c|c|c|c|c|c|c|}
\hline $\begin{array}{l}\text { No. } \\
\text { Variabel }\end{array}$ & $\begin{array}{l}\text { (Importance } \\
\text { to Customers) }\end{array}$ & $\begin{array}{c}\text { (Customers Satisfaction } \\
\text { Performance) }\end{array}$ & Goal & Gap & $\begin{array}{l}\text { Improvemen } \\
\text { t Ratio }\end{array}$ & $\begin{array}{c}\text { Raw } \\
\text { Weight }\end{array}$ & $\begin{array}{c}\text { Normalized Raw } \\
\text { Weight }\end{array}$ \\
\hline 1. & 3,820 & 3,862 & 4 & 0,042 & 1,036 & 3,957 & 0,031 \\
\hline 2. & 3,461 & 3,778 & 4 & 0,317 & 1,059 & 3,664 & 0,029 \\
\hline 3. & 3,898 & 4,006 & 4 & 0,108 & 0,999 & 3,892 & 0,030 \\
\hline \multicolumn{8}{|c|}{ Tabel 2. Perhitungan House of Quality (Lanjutan) } \\
\hline $\begin{array}{c}\text { No. } \\
\text { Variabel }\end{array}$ & $\begin{array}{c}\text { (Importance to } \\
\text { Customers) }\end{array}$ & $\begin{array}{c}\text { (Customers Satisfaction } \\
\text { Performance) }\end{array}$ & Goal & Gap & $\begin{array}{l}\text { Improvem } \\
\text { ent Ratio }\end{array}$ & $\begin{array}{c}\text { Raw } \\
\text { Weight }\end{array}$ & $\begin{array}{c}\text { Normalized Raw } \\
\text { Weight }\end{array}$ \\
\hline 4. & 3,820 & 3,868 & 4 & 0,048 & 1,034 & 3,950 & 0,031 \\
\hline 5. & 3,701 & 3,772 & 4 & 0,072 & 1,060 & 3,924 & 0,031 \\
\hline 6. & 3,401 & 3,509 & 4 & 0,108 & 1,140 & 3,877 & 0,030 \\
\hline 7. & 4,162 & 3,192 & 4 & $-0,970$ & 1,253 & 5,216 & 0,041 \\
\hline 8. & 3,832 & 3,838 & 4 & 0,006 & 1,042 & 3,994 & 0,031 \\
\hline 9. & 3,725 & 3,832 & 4 & 0,108 & 1,044 & 3,888 & 0,030 \\
\hline 10. & 3,719 & 3,772 & 4 & 0,054 & 1,060 & 3,943 & 0,031 \\
\hline 11. & 4,257 & 4,407 & 4 & 0,150 & 0,908 & 3,864 & 0,030 \\
\hline 12. & 4,563 & 3,263 & 4 & $-1,299$ & 1,226 & 5,593 & 0,044 \\
\hline 13. & 4,802 & 2,569 & 4 & $-2,234$ & 1,557 & 7,478 & 0,059 \\
\hline 14. & 4,150 & 4,455 & 4 & 0,305 & 0,898 & 3,726 & 0,029 \\
\hline 15. & 4,635 & 2,413 & 4 & $-2,222$ & 1,658 & 7,682 & 0,060 \\
\hline 16. & 4,305 & 2,749 & 4 & $-1,557$ & 1,455 & 6,266 & 0,049 \\
\hline 17. & 4,389 & 2,054 & 4 & $-2,335$ & 1,948 & 8,548 & 0,067 \\
\hline 18. & 4,216 & 3,162 & 4 & $-1,054$ & 1,265 & 5,333 & 0,042 \\
\hline 19. & 4,772 & 2,413 & 4 & $-2,359$ & 1,658 & 7,911 & 0,062 \\
\hline 20. & 4,036 & 4,198 & 4 & 0,162 & 0,953 & 3,846 & 0,030 \\
\hline 21. & 4,749 & 2,407 & 4 & $-2,341$ & 1,662 & 7,891 & 0,062 \\
\hline 22. & 3,922 & 4,054 & 4 & 0,132 & 0,987 & 3,870 & 0,030 \\
\hline 23. & 3,976 & 4,096 & 4 & 0,120 & 0,977 & 3,883 & 0,030 \\
\hline 24. & 3,180 & 3,383 & 4 & 0,204 & 1,182 & 3,759 & 0,029 \\
\hline 25. & 3,192 & 3,228 & 4 & 0,036 & 1,239 & 3,955 & 0,031 \\
\hline 26. & 3,467 & 3,581 & 4 & 0,114 & 1,117 & 3,873 & 0,030 \\
\hline
\end{tabular}

$$
\text { Normalized Raw weight }=\begin{aligned}
& \sum \text { Raw Weight } \\
& \text { Raw Weight } \frac{\dot{i}}{\dot{i}}
\end{aligned}
$$

Hasil perhitungan tingkat kepentingan pelanggan (Importance to Customers), tingkat kepuasan pelanggan (Customers Satisfaction Performance), goal, gap, improvement ratio, raw weight, dan normalized raw weight dapat dilihat pada Tabel 2.

Tabel 2. Perhitungan House of Quality

(Sumber: Hasil Perhitungan) 
Berdasarkan hasil perhitungan pada Tabel 2 diambil 5 varibel yang tertinggi berdasarkan hasil perhitungan gap dan raw weight yaitu sarana ruang terbuka hijau, perkerasan jalan/paving, keamanan terhadap banjir, kondisi dan jalan utama serta fasilitas pembuangan air kotor/drainase.

\section{Respon Teknis}

Respon teknis berisi tentang pihak developer menerjemahkan keinginan atau kebutuhan konsumen. Keinginan atau kebutuhan konsumen tersebut diterjemahkan dalam bahasa teknik yang digunakan untuk menentukan target yang akan dicapai. Respon Teknis dapat dilihat pada Tabel 3.

Tabel 3. Respon Teknis

\begin{tabular}{ccc}
\hline No & Variabel & Respon Teknis \\
\hline 1. & Sarana Ruang & Penyediaan fasilitas \\
& Terbuka Hijau & umum dan RTH (Ruang \\
& (RTH) & Terbuka Hijau) \\
2. & Perkerasan jalan/ & Membangun prasarana \\
& paving & jalan yang memadai \\
& & sesuai peraturan \\
\hline
\end{tabular}

Tabel 3. Respon Teknis (Lanjutan)

\begin{tabular}{ccc}
\hline No & Variabel & Respon Teknis \\
\hline 3. & $\begin{array}{c}\text { Keamanan terhadap } \\
\text { banjir }\end{array}$ & $\begin{array}{c}\text { Penyediaan fasilitas } \\
\text { pos dan bak sampah } \\
\text { Penyediaan petugas } \\
\text { keamanan }\end{array}$ \\
4. & $\begin{array}{c}\text { Lebar dan kondisi } \\
\text { jalan utama }\end{array}$ & $\begin{array}{c}\text { Membangun prasarana } \\
\text { jalan yang sesuai } \\
\text { standar peraturan }\end{array}$ \\
5. & Fasilitas & $\begin{array}{c}\text { Perbaikan drainase } \\
\text { pembuangan air } \\
\text { kotor/ drainase }\end{array}$ \\
& & Penyediaan petugas \\
& & kebersihan \\
\hline
\end{tabular}

(Sumber : Pihak Developer PT. Sobo Asri)

\section{Analisis IPA}

Pada bagian ini menjelaskan mengenai pemetaan dari nilai kepuasan konsumen ( $\mathrm{x}$ ) dan nilai kepentingan konsumen (y), dari hasil tersebut maka akan terbentuk matriks yang terdiri dari empat kuadran. Masing-masing kuadran menggambar skala prioritas dalam mengambil keputusan untuk strategi perbaikan berupa peningkatan kualitas maupun mempertahankan kualitas. Matriks Importance Performance Analysis dapat dilihat pada Gambar 3.

Berdasarkan pada Gambar 3 maka dapat diinterpretasikan sebagai berikut:

\section{Kuadran A}

Kuadran A menunjukkan faktor atau variabel yang dianggap penting oleh pelanggan namun tidak terlaksana dengan baik oleh PT. Sobo Asri. Variabel-variabel yang termasuk dalam kuadran A adalah:

(7) Kerusakan lantai terhadap keretakan.

(12)Fasilitas pembuangan air limbah/air kotor.

(13) Fasilitas pembuangan air hujan/drainase

(15) Lebar dan kondisi jalan utama.

(16) Lebar dan kondisi jalan di depan rumah.
(17) Sarana ruang terbuka hijau/pemakaman.

(18) Penerangan jalan.

(19) Perkerasan jalan/paving.

(21) Keamanan terhadap banjir.

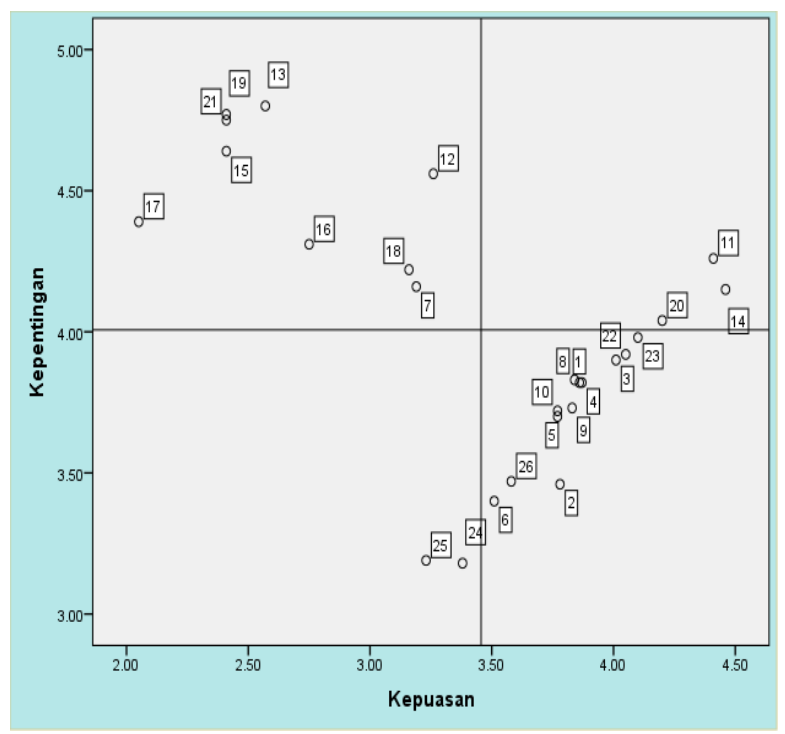

Gambar 3. Matriks Importance Performance Analysis

\section{Kuadran B}

Kuadaran B menunjukkan faktor variabel yang dianggap penting dan memuaskan pelanggan yang sudah dilaksanakan dengan baik oleh PT Sobo Asri. Variabelvariabel yang termasuk dalam kuadran $\mathrm{B}$ adalah:

(11) Fasilitas penyediaan air bersih/PDAM.

(14) Failitas listrik.

(20) Keamanan lokasi perumahan.

\section{Kuadran $\mathrm{C}$}

Kuadran $\mathrm{C}$ menunjukkan faktor atau variabel yang dianggap kurang penting oleh pelanggan dan tidak terlaksana dengan baik oleh PT Sobo Asri. Variabelvariabel yang termasuk dalam kuadran $\mathrm{C}$ adalah:

(24) Kepedulian akan kritik dan saran

(25) Perhatian akan kebutuhan penghuni

\section{Kuadran D}

Kuadran D menunjukkan faktor atau variabel yang tingkat kepentingannya rendah tetapi memiliki tingkat kepuasan yang tinggi. Variabel-variabel yang termasuk dalam kuadran $\mathrm{D}$ adalah:

(1) Denah rumah.

(2) Jumlah kamar.

(3) Kualitas bahan yang digunakan dalam pembangunan.

(4) Ketahanan atap rumah.

(5) Ketahanan dinding terhadap keretakan struktur.

(6) Kerusakan cat dinding dalam rumah.

(8) Ketahanan plafon.

(9) Sirkulasi udara dan efektifitasnya.

(10) Kualitas pencahayaan.

\section{Strategi Perbaikan}

Berdasarkan hasil analisis IPA yang terdapat pada kuadran A strategi perbaikan yang perlu dilakukan oleh PT Sobo Asri untuk memenuhi kepuasan pelanggan yaitu: 
1. Melakukan kebersihan secara berkala dengan cara mengkoordinir petugas kebersihan unuk membersihkan selokan utama setiap dua minggu sekali.

2. Melakukan perbaikan drainase dengan ukuran kedalaman $40 \mathrm{~cm}$ dengan kemiringan maksimal $2 \%$.

3. Ukuran lebar jalan Lokal Sekunder I lebar perkerasan \pm 3 $\mathrm{m}-7 \mathrm{~m}$. Jalan Lokal Sekunder II lebar perkerasan $\pm 3 \mathrm{~m}-$ $6 \mathrm{~m}$. Dengan ketebalan paving $6 \mathrm{~cm}$.

Pada saat rumah akan diserahkan kepada penghuni, sebelumnya dilakukan pengecekan terlebih dahulu dari kualitas rumah sampai instalasi saluran air dan listrik.

\section{KESIMPULAN}

Berdasarkan hasil analisis data dapat disimpulkan sebagai berikut:

1. Berdasarkan hasil observasi langsung, hasil identifikasi kondisi eksisting di lapangan pada Perumahan Griya Pesona Karangrejo dengan standar peraturan perumahan yang ada belum sepenuhnya memenuhi standar. Beberapa analisis yang belum memenuhi yaitu dari segi kualitas produk dan sarana prasarana.

2. Variabel yang diprioritaskan dan dipentingkan oleh penghuni terhadap faktor kualitas, sarana prasarana dan lokasi pada perumahan Griya Pesona Karangrejo Banyuwangi berdasarkan nilai gap dan raw weight berikut 5 variabel yang berada diurutan tertinggi yaitu Sarana ruang terbuka hijau/pemakaman, Perkerasan jalan/paving, Keamanan terhadap banjir, Lebar dan kondisi jalan serta Fasilitas pembuangan air hujan/drainase.

3. Berdasarkan hasil analisis IPA strategi perbaikan yang perlu dilakukan oleh PT Sobo Asri untuk memenuhi kepuasan pelanggan yaitu:

1.Melakukan kebersihan secara berkala dengan cara mengkoordinir petugas kebersihan untuk membersihkan selokan setiap dua minggu sekali.

2. Melakukan perbaikan drainase dengan ukuran kedalaman $40 \mathrm{~cm}$ dengan kemiringan maksimal $2 \%$.

3. Ukuran lebar jalan Lokal Sekunder I lebar perkerasan \pm 3 m-7 m. Jalan Lokal Senkunder II lebar perkerasan $\pm 3 \mathrm{~m}-6 \mathrm{~m}$. Dengan ketebalan paving $6 \mathrm{~cm}$.

Pada saat rumah akan diserahkan kepada penghuni, sebelumnya dilakukan pengecekan terlebih dahulu dari kualitas rumah sampai instalasi saluran air dan listri.

\section{DAFTAR PUSTAKA}

[1] Aditya Wahyu. 2013. Penerapan Metode QFD (QUALITY Function Deployment) Pada Rencana Pengembangan Sekolah Di SMKN 2 Yogyakarta. Yogyakarta: Jurnal Teknik Universitas Negeri Yogyakarta.

[2] Daniel Lukman. 2016. Pengaruh Lokasi, Pelayanan, Fasilitas Dan Harga Terhadap Kepuasan Konsumen Property "Green Garden Resident". Semarang.: Jurnal FEB.

[3] Keputusan Menteri Permukiman dan Prasarana Wilayah No. 403/KPTS/M/2002. Pedoman Teknis Pembangunan Rumah Sederhana Sehat (Rs SEHAT). 2 Desember 2002. Jakarta.
[4] ISNI 03-6967-2003. Persyaratan Umum Sistem Jaringan dan Geometrik Jalan Perumahan. 21 Agustus 2001. Bandung .

[5] SNI 03-1733-2004. Tata Cara Perencanaan Lingkungan Perumahan di Perkotaan. 17 Juni 2003. Bandung.

[6] Wahyu Supriyanto dan Rini Iswandiri. 2017. Kecenderungan Sivitas Akademik Dalam Memilih Sumber Referensi Untuk Penyusunan Karya Tulis Ilmiah Di Perguruan Tinggi. Yogyakarta: Jurnal Berkala Ilmu Perpustakaan dan Informasi. 